\title{
ECOLOGICAL INDICES OF FRESHWATER COPEPODS AND CLADOCERANS FROM DHARMAPURI DISTRICT, TAMIL NADU
}

\author{
K. Sivakumar and K. Altaff*
}

Unit of Reproductive Biology and Live Feed Culture, Department of Zoology, The New College, Chennai, Tamil Nadu 600014, India * Email: kaltaff@rediffmail.com (Corresponding author)

\begin{abstract}
Four copepods and seven cladoceran species were identified in the zooplankton samples collected from fifty freshwater bodies, in and around Dharmapuri District, Tamil Nadu including during September 1999 and April, 2000. Ecological indices for similarity and dissimilarity, index of dominance, index of diversity, index of evenness and species richness indicate variations pertaining to winter and summer zooplankton density. Zooplankton populations of winter and summer are discussed.
\end{abstract}

\section{KEYWORDS}

Copepods, cladocerans, dominance, diversity, evenness, species richness

Zooplankton populations of tropical freshwater bodies depend on the primary productivity and physico-chemical parameters. Copepods and cladocerans constitute the dominant groups of freshwater habitat. They inhabit the ponds, lake, rivers and reservoirs and reported to occur more abundantly in ponds and lakes than in rivers (Reid, 1986; Raghunathan, 1983; Sharma, 1991). Some genera of copepods and cladocerans are cosmopolitan in distribution, while others are restricted to some continents (Brooks, 1959; Williamson, 1991). Depth of the pond, water transparency, $\mathrm{pH}$ and predators determine the distribution and abundance of copepods (Confer et al., 1983; Patalas, 1971). Dussart (1984) reviewed the systematic and distribution of tropical freshwater zooplankton from all over the world.

The successions of zooplankton populations depend upon the interspecific and intraspecific interaction and predation potential (Fernando, 1980). There has been some report on the species composition and species diversity of harpacticoid copepod in tropical reef lagoon (Villers \& Bodiou, 1996). The freshwater bodies such as ponds, lakes, rivers and reservoirs of Dharmapuri district, Tamil Nadu characterize tropical freshwater ecosystem. The present paper deals with the copepod and cladoceran populations of fifty freshwater bodies with regard to ecological indices of winter and summer populations.

\section{Materials ANd Methods}

Zooplankton samples were collected during September, 1999 (winter) and April, 2000 (summer) from fifty freshwater bodies of Dharmapuri District, Tamil Nadu. Samples were collected during early hours of the day (6.00am), using a plankton net made up of bolten silk (mesh size $100 \mu \mathrm{m})$

During the study period temperature and $\mathrm{pH}$ of the water sample were recorded. The samples were preserved in 5\% neutral buffer formalin for qualitative analysis and identified following the taxonomic keys provided by Rajendran (1973), Pennak (1978), Tonapi (1980), Barnes (1982), Battish (1992), Maas (1994), Reddy (1994) and, Dussart and Defaye (1995) for copepods and Michael (1973), Venkataraman (1983), Sharma and Michael (1987), Raghunathan (1989) and Murugan et al. (1998) for cladocerans. For quantitative analysis, 100L of water sample was filtered through the plankton net and the plankton sample was carefully transferred with out any loss to a plastic container and preserved in $5 \%$ neutral buffer formalin.

Copepods and cladocerans were enumerated using SedgewickRafter chamber following Santhanam et al. (1989). The data was analyzed for ecological indices such as similarity and dissimilarity, index of dominance, index of diversity, index of evenness and species richness following the methods described by Odum (1983).

\section{Results}

Copepods and cladocerans recorded from fifty freshwater bodies of Dharmapuri District, Tamil Nadu were:

Copepods: 1. Heliodiaptomus viduus 2. Sinodiaptomus (Rhinediaptomus) indicus 3. Thermocyclops hyalinus 4. Mesocyclops aspericornis 5. copepodid and 6. nauplii

Cladocerans: 1. Daphnia carinata 2. Moina micrura 3. Moina brachiata 4. Diaphanasoma sarsi 5. Diaphanasoma excisum 6. Ceriodaphnia cornuta and 7. Alona quadrangularis.

Temperature and $\mathrm{pH}$ were normal in range $\left(30 \pm 2^{\circ} \mathrm{C} \& 6.3-8\right.$ respectively).

In dissimilarity analysis values were divided into four ranges i) $0.1-0.25$, ii) $0.26-0.50$, iii) $0.51-0.75$ and iv) $0.76-1.00$ and were framed as matrices. In winter season, dissimilarity values of $H$. viduus and $S$. (R.) indicus and, $S$. (R.) indicus and T. hyalinus were in the range of 0.51-0.75 and other animal dissimilarity values were in the same range (0.76-1.00). Different species of copepods showed similar range of dissimilarity $(0.51-0.75)$ in summer season (Fig. 1).

In cladocerans, during winter season $D$. sarsi and M. micrura showed lesser dissimilarity values (0.1-0.25). Range of dissimilarities values for $D$. sarsi and C. cornuta and, C. cornuta and $M$. micrura were $0.26-0.50, D$. carinta and M. micrura showed 0.51-0.76, while in other cladocerans it ranged between 0.76-1.00. During summer season, D. sarsi and M. micrura and, $D$. sarsi and C. cornuta showed dissimilarity range of $0.51-$ 0.75 , however, $M$. micrura and $C$. cornuta showed a range of $0.26-0.50$, while other cladocerans showed similar range $(0.76-$ 1.00) (Fig. 1-4). 
Table 1. Ecological indices of planktonic copepods and cladocerans in winter (Sep., 1999) and summer (Apr., 2000) seasons in Dharmapuri District

\begin{tabular}{|c|c|c|c|c|c|c|c|c|}
\hline \multirow[t]{2}{*}{ Zooplankton } & \multicolumn{4}{|c|}{ Winter } & \multicolumn{4}{|c|}{ Summer } \\
\hline & C & $\mathbf{H}$ & e & d & C & $\mathbf{H}$ & e & d \\
\hline \multicolumn{9}{|l|}{ Copepods } \\
\hline Heliodiaptomus viduus & 0.0023 & 4.2147 & 2.3522 & 1.0965 & 0.0057 & 2.7293 & 1.6958 & 0.6993 \\
\hline $\begin{array}{l}\text { Sinodiaptomus } \\
\text { (Rhinediaptomus) indicus }\end{array}$ & 0.0049 & 2.7293 & 1.5232 & 0.8206 & 0.0041 & 2.8734 & 1.7854 & 0.7207 \\
\hline Thermocyclops hyalinus & 0.0676 & 1.6071 & 0.8969 & 0.6748 & 0.2959 & 1.1528 & 0.7163 & 0.5202 \\
\hline Mesocyclops aspericornis & 0.0006 & 3.7537 & 2.0949 & 0.9921 & - & - & - & - \\
\hline Copepodid & 0.0910 & 1.5040 & 0.8394 & 0.6614 & 0.0253 & 1.9979 & 1.2414 & 0.6182 \\
\hline nauplii & 0.1090 & 1.4387 & 0.8209 & 0.6536 & 0.0246 & 2.0085 & 1.2480 & 0.6202 \\
\hline \multicolumn{9}{|l|}{ Cladocerans } \\
\hline Daphnia carinata & 0.0026 & 3.0269 & 1.8808 & 0.7561 & - & - & - & - \\
\hline Moina micrura & 0.0083 & 1.5279 & 0.9494 & 0.5674 & 0.0543 & 1.6997 & 1.0561 & 0.6462 \\
\hline Moina brachiata & - & - & - & - & 0.0008 & 3.5695 & 2.2179 & 0.9770 \\
\hline Diaphanasoma sarsi & 0.1013 & 1.4594 & 0.9068 & 0.5602 & 0.0418 & 1.7706 & 1.1001 & 0.6600 \\
\hline Diaphanasoma excisum & 0.00004 & 5.0735 & 3.1524 & 1.2461 & - & - & - & - \\
\hline Ceriodaphnia cornuta & 0.1107 & 1.4 .387 & 0.8939 & 0.5571 & 0.2836 & 1.1649 & 0.7258 & 0.5698 \\
\hline Alona quadrangularis & - & - & - & - & 0.000002 & 6.5727 & 4.0839 & 3.6430 \\
\hline
\end{tabular}

$\mathrm{C}$ - index of dominance, $\mathrm{H}$ - index of diversity, e - index of eveness, $\mathrm{d}$ - species richness

Higher index of dominance was recorded in nauplii (0.1090) and copepodid (0.0910) of copepods and T. hyalinus (0.0676). Among cladocerans, C. cornuta (0.1107) D. sarsi (0.1013) and M. micrura (0.0853) showed high dominance value. In summer season, T. hyalinus and C. cornuta showed highest dominance of 0.2959 and 0.2836 respectively, while $A$. quadrangularis was least dominant (0.000002) (Table.1).

In winter, Diversity, abundance and density values for $H$. viduus were 4.2147, 2.3522 and 1.0965, for M. aspericornis 3.7537, 2.0949 and 0.9921 , for $S$. (R.) indicus $2.7293,1.5232$ and 0.8206 , for $D$. excisum 5.0735, 3.1524 and 1.2461 and for D. carinata 3.0269 , 1.8088 and 0.7561 respectively. In summer season, $S$. (R.) indicus, H. viduus, nauplii of copepods, A. quadrangularis and $M$. brachiata showed high diversity, abundance and density, while $T$. hyalinus $(1.1528,0.7163$ and 0.5202$)$ and $C$. cornuta ( $1.1649,0.7258$ and 0.5698 ) showed lowest diversity, abundance and density. M. brachiata and A. quadrangularis were absent in winter, while $M$. aspericornis, D. carinata and D. excisum were absent in summer (Table. 1).

\section{Discussion}

In this study $H$. viduus and $S$. (R.) indicus, $S$. (R.) indicus and T. hyalinus showed similar dissimilarity range in both the seasons, but $H$. viduus and $T$. hyalinus showed similar range during summer season, whereas in winter season other copepods showed similar range (0.76-1.00).

In cladocerans, species dissimilarity ranged between $0.76-1.00$ during winter and summer season and showed 6 and 7 combinations respectively. Nishida (1985) stated matrix of dissimilarity of coefficient of Oithoninae family of genera Oithona sp. and Paroithona sp., which is a dense assemblage of closely allied species.

High dominance of species was recorded during winter season than in summer but $T$. hyalinus and $C$. cornuta showed high dominance during summer season in fifty samples. In the samples, one or two species dominated during study period such type of results have been reported by Villers and Bodiou (1996).

Index of diversity of the present study showed $H$. viduus and $D$. excisum with high value in winter and, $S$. (R.) indicus and $A$. quadrangularis with high value in summer. Lyons (1981) had shown that biomass or productivity, which are often more ecologically appropriate, can be used in such statistical tests if number of individuals are also known.

Odum (1983) suggested that two broad approaches are used to analyse species diversity in different situations of dominance - diversity, relative abundance curves and diversity indices, which are ratios or other mathematical expression of species importance relationships.

In the present study, abundance and density increased with diversity value. Diversity is directly related to abundance or equitability (Odum, 1983). Villers and Bodiou (1996) reported that, harpacticoid copepods showed lowest values of diversity and equitability, but the greatest degree of dominance in single species. Similar type of results were obtained with regard to ecological indices, which also coincide with Odum (1983) that the dominance value is inversely proportional to values of diversity, evenness and species richness.

Species diversity is reported to be influenced by the functional relationships between the tropic levels. The amount of predation greatly affects the diversity of prey population (Odum, 1983). The reason for low diversity values of nauplii and copepodid of copepods and C. cornuta recorded in the present study might be that, they are preferred by predators (fish).

\section{REFERENCES}

Barnes, R.D. (1982). Invertebrate Zoology. Saunders College. Philadephia. Japan.

Battish, S.K. (1992). Freshwater Zooplankton of India. Oxford IBH Publishing Co. Pvt. Ltd. New Delhi. 

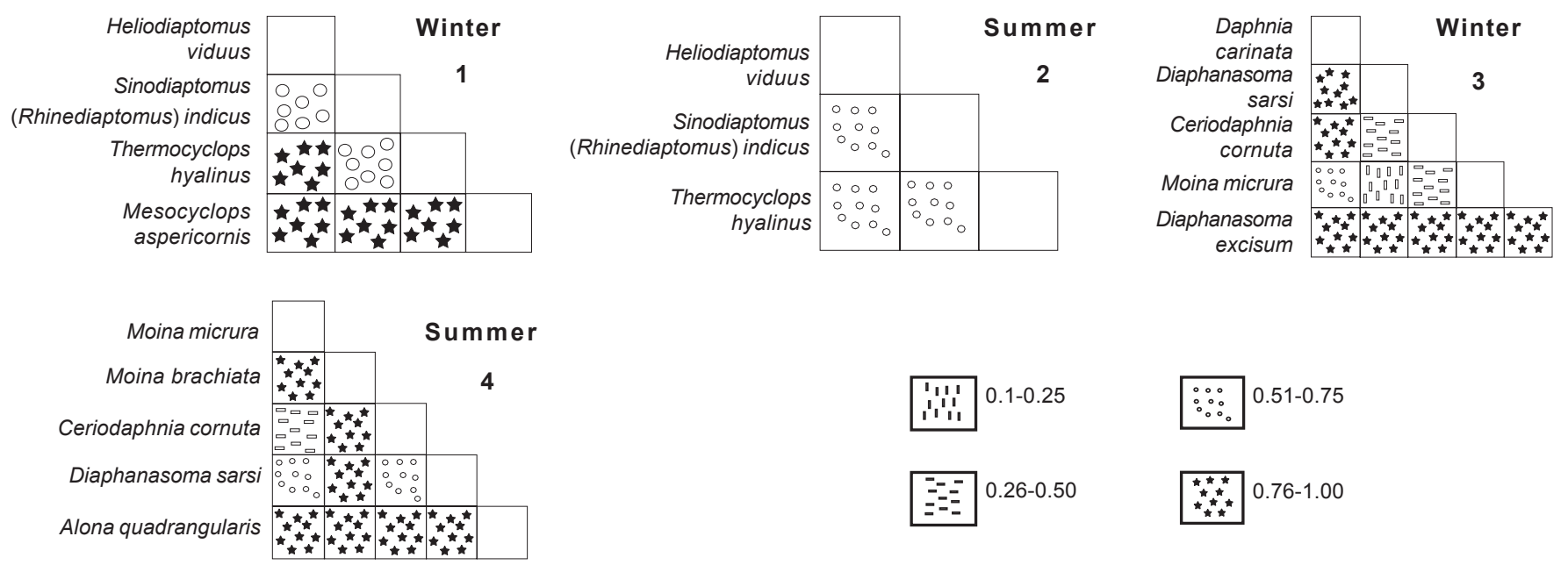

Figures 1-4. Matrices of dissimilarity values of copepods and cladocerans during winter and summer seasons

Brooks, J.L. (1959). Cladocera. In: Edmondson, W.T. (editor). Freshwater Biology. John Wiley \& Sons, New York. Pp.587-656. Confer, J.L. T. Kaaretand G.E. Likens (1983). Zooplankton diversity and biomass in recently acidified lakes. Canadian Journal of Fisheries and Aquaculture Science 40: 36-42.

Dussart, B.H. (1984). Some Crustacea Copepoda from Venezuela. Hydrobiologia 113: 25-64.

Dussart, B.H. and D. Defaye (1995). Copepoda. Introduction to the Copepoda. SPB Academic Publishing, Netherlands. 253pp.

Fernando, C.H. (1980). The freshwater Zooplankton of Sri Lanka with a discussion of tropical freshwater zooplankton cosmopolitan. International Reviews Gesture of Hydrobiologia. 65pp.

Lyons, N.L. (1981). Comparing diversity indices based on counts weighted by biomass or other importance values. American Nature 118: 438-442.

Maas, S. (1994). Introduction to the copepoda. International Training Course: Lake Zooplankton: a tool in lake management 218pp.

Michel, R.G. (1973). Cladocera: A guide to the study of freshwater organisms. Journal of Madurai University, Supplement 1: 71-85.

Murugan, N., P. Murugavel and M.S. Kodarkar (1998). Cladocera. Indian Association of Aquatic Biologist. 55pp.

Nishida. S. (1985). Taxonomy and distribution of the family Oithonidae (Copepoda, Cyclopoida) in the Pacific and Indian Oceans. Bulletin of the Ocean Research Institute University of Tokyo 20: 1-167.

Odum, E.P. (1983). Basic Ecology. Holt-Saunders International Editions. Saunders College Publishing. Japan, 558pp.

Patalas, K. (1971). Crustacean plankton communities in forty-five lakes in the experimental lakes area, North Western Ontario. Journal of Fisheries Research Board of Canada 28: 231-244.

Pennak, R.W. (1978). Freshwater Invertebrates of the United States, $2^{\text {nd }}$ edition. John Wiley and Sons, New York, 803p.

Raghunathan, M.B. (1983). Studies on some planktonic cladocerans (Crustacea) of Tamil Nadu, Ph.D. Thesis, Madras Unversity (unpublished). Raghunathan, M.B. (1989). Indian Cladocera (Crustacea). Indian Review in Life Sciences 9: 137-152.

Rajendran, M. (1973). Copepoda. In: Michael R.G.(Ed.) A guide to the study of freshwater organisms. Journal of Madurai University, Supplement 1: 103.

Reddy, Y.R. (1994). Guides to the identification of the microinvertebrates of the continental waters of the world. Dumont, H.J.F. (editor). Copepoda: Calanoida: Diaptomidae. SPB Academic Publications, The Netherlands, $221 \mathrm{pp}$.

Reid, J.W. (1986). Some usually overlooked cryptic copepod habitats. Syllogeus. 58. Proceedings of Second International Conference on Copepoda, Ottawa, 84: 594-598.
Santhanam, R.P. Velayutham and G.Jegathesan. (1989). A Manual of Freshwater Ecology. Daya Publishing House, New Delhi.

Sharma, B.K. (1991). Cladocera: Animal Resources of India. pp. 205-223.

Sharma, B.K. and R.G. Michael (1987). Reviews of taxonomic studies on freshwater cladocera form India with remarks on biogeography. Hydrobiologia 145: 29-33.

Tonapi, G.T. (1980). Freshwater Animals of India. Oxford IBH publishing Co. Pvt. Ltd. New Delhi.

Venkataraman, K. (1983). Taxonomy and ecology of Cladocera of Southern Tamil Nadu. Ph.D. Thesis. Madurai Kamaraj University, Madurai.

Villers, L. and J.Y. Bodiou (1996). Community structure of harpacticoid copepods in a tropical reef lagoon (Fangataufa Atoll-French Polynesia). Oceanologia Acta 19(2): 155-162.

Williamson, C.E. (1991). Copepoda. Ecology and Classification of North American Freshwater Invertebrates. Academic Press, Inc. pp. 787822.

Whittakar, R.H. (1960). Vegetation of the Siskiyou Mountains, Oregon and California. Ecology Monography 30: 279-338.

\section{ACKNOWLedgements}

The authors are thankful to the UGC, New Delhi for the financial assistance through a research project (UGC F-3-75/2001 SR.II) for this work. 